\title{
Drought resistance of apple tree and raspberry varieties and forms promising for the Crimea region
}

\author{
Z.I. Arifova*, E.F. Chelebiev, A.V. Smykov, E.S. Khalilov, and M.K. Uskov \\ Federal State Budgetary Institution of Science "Nikitsky Botanical Garden of Order of the Red \\ Banner of Labor - National Scientific Center of the Russian Academy of Sciences", Yalta, Russia
}

\begin{abstract}
The article presents the results of studying the water regime and drought resistance of varieties and breeding forms of apple tree and raspberry of domestic and foreign breeding of the collection of the FSBSI "NBS-NSC" in laboratory conditions using the method of leaf dehydration. The varieties of apple tree - Favorit and raspberry - Balsam released in the Crimea were taken as a control. Based on the performed studies, groups of promising varieties and breeding forms of apple tree (Valyuta, 12-14-78, 25-25-80, 2-11-7-80) and raspberry (Glen Ample, Gusar, Krepysh, 11/15) with a high level of water retention capacity and turgescence were identified. These varieties and forms are of interest for inclusion in the breeding process for drought resistance trait, and are also recommended for introduction into production in the arid conditions of the foothill zone of the Crimea.
\end{abstract}

\section{Introduction}

The climatic conditions of the Crimea foothill zone are not always favorable for fruit and berry crops. High air temperature and low relative humidity, typical for the summer period of the region, have a negative impact on the growth and development of plants. The discrepancy between the plant's need for moisture and its supply from the soil as a result of insufficient precipitation leads to a decrease in yield. Excessive loss of water by the plant during drought causes water regime violation and weakening of physiological processes. Drought-resistant plants have less water loss than non-drought-resistant plants.

An important role in regulation of water exchange process is played by cell moistureretaining capacity, which is associated with the content of osmotically active and colloidal substances in them. The water retention capacity depends on the reaction of respiratory apparatus to the effects of extreme environmental factors. It is known that the leaves of drought-resistant plants give off less water during wilting than the leaves of less resistant plants $[1,2]$. Free water is involved in the metabolism, and bound water provides the waterretaining capacity of leaf cells. Metabolism is disrupted with a lack of water, protein and carbohydrate $[3,4]$. Nevertheless, some authors believe that it is not always possible to

* Corresponding author: arifova.zera.sanie@mail.ru 
judge drought resistance only by water loss, it is also important to take into account the process of leaf blade turgor restoration [5].

The leading fruit crop in the Crimea is the apple tree, which is widely distributed due to its high biological and economic indicators: adaptability to various soil and climatic conditions; high yield and fruit quality. They have an attractive appearance, good taste, and are in great demand among consumers. A promising direction for improving horticulture efficiency is the introduction of highly productive varieties of this crop that are resistant to adverse environmental factors [6]. The study of the drought resistance of apple tree is primarily associated with the study of water regime, which determines the physiological parameters (leaf water content, water loss by leaves, water content restoration) and makes it possible to assess the variety resistance to a lack of moisture [7].

The popularity of raspberry crop is due to early maturity, annual fruiting, high taste and technological qualities of the berries. They are rich in vitamins, trace elements, sugars and organic acids, which ensures its high value for the human body. The cultivation of berry crops contributes to a higher profit compared to other fruit crops [8]. With the emergence of new varieties having a complex of economically valuable traits, it becomes necessary to identify among them samples that are adaptive to certain growing conditions. In connection with extreme influence of climatic conditions on raspberry plants, which has been observed recently, the study of water regime parameters, influence of drought, as well as resistance to water stress is of particular relevance. The lack of moisture leads to decrease in yield, ovary and berries shattering, and violation of water metabolism in raspberry shrubs [9].

The ability of drought-resistant apple tree and raspberry varieties to withstand a longterm lack of water is one of the main conditions for the successful cultivation of these crops in the Crimea.

The purpose of the research was to study drought resistance of promising varieties and forms of apple tree and raspberry on the basis of indicators of their water regime.

\section{Conditions, materials and methods of research}

The geographical location of the Crimea provides a large amount of heat in summer and winter. The sunshine duration is up to 2,500 hours per year. On average, the sun shines 5-7 hours a day. The frost-free period averages 170 days. The number of days with frost in the steppe and foothill zone is 110-120 days [10-13].

The climate is dry-steppe, with mild winters with little snow and hot, long summers. The average air temperature of $20.5-21.3^{\circ} \mathrm{C}$ is the warmest period according to the observations of the weather station of the KOSS FSBSI NBS-NNC department in July August, and the coldest in January - 2.4. Absolute low temperatures in January do not exceed minus $12.9^{\circ} \mathrm{C}$, maximum (July) $+35.5^{\circ} \mathrm{C}$. At this time, easterlies bring dry winds, atmospheric droughts. The average annual precipitation is $453 \mathrm{~mm}$.

During the years of research (2018-2020), the average monthly temperatures of JulyAugust were in the range of $+20.9 \ldots+22.9^{\circ} \mathrm{C}$, the relative humidity was $69-76 \%$, the amount of precipitation for the summer period was 196.6-206.6, including in July-August from 26.8 to $113 \mathrm{~mm}$. This period was characterized by extremely arid conditions, the plants were exposed to atmospheric drought.

To determine the degree of drought resistance, 10 samples of promising apple tree varieties and forms were studied - Favorit (control), Arbat, Assol, Valyuta, Phoenix, 2-525-80, 2-7-2-80, 2-11-7-80, 12-14-78, 69-2-08.

The study of raspberry drought resistance included 10 promising varieties - Balsam (control), Vikinite, Glen Ampl, Gusar, Kovichan, Krepysh, Patricia, Persea and breeding forms 11/15 (Patricia $\times$ Persea), 28/15 (Phenomen $\times$ Persea). Drought resistance was analyzed by taking samples (leaves) in critical moisture supply periods (July - August). 
The leaves were taken in the morning. The study of apple tree and raspberry drought resistance was carried out by the method of artificial wilting of leaves.

Records and observations were carried out using the Program and methods of variety study of fruit, berry and nut crops [14]; Programs and methods of fruit, berry and nut crops selection [15]. Drought resistance was determined according to the methodological recommendations of G.N. Eremeev [16]. Statistical processing of the results was carried out according to the method of B.A. Dospekhov field experience [17], using the programs Statistics-10 and Microsoft Office [18].

\section{Results and their discussion}

Abiotic and biotic stresses, including drought and disease, threaten the apple production in the world. Drought often leads to a decrease in photosynthetic capacity (reducing the size of stomatal holes, which limits $\mathrm{CO}_{2}$ absorption, and reducing the photosynthetic activity of tissues containing chlorophyll), and transport of solutes, loss of turgescence, peroxidation of membrane lipids, and other problems in apple trees. Peroxidation of membrane lipids under drought stress always leads to secondary oxidative stress. An increase in the level of reactive oxygen intermediates (ROI), such as hydrogen peroxide $\left(\mathrm{H}_{2} \mathrm{O}_{2}\right)$, is the most direct indicator of oxidative stress; and malondialdehyde (MDA) is a product of membrane lipids peroxidation [19-21].

In order to identify the most promising varieties and forms of apple tree according to the degree of drought resistance, 10 samples were analyzed. As a result, it was found that Valyuta variety (35.19\%) and form 12-14-78 (34.40\%) were distinguished by a high water retention capacity (Table 1). To a lesser extent, the water-retaining ability was manifested in forms $2-11-7-80$ and $2-5-25-80(41.56-42.43 \%)$. In the control variety Favorit, it was $58.45 \%$.

When analyzing the ability to restore turgor after wilting, it was found that it is different in all samples and is genotypically determined. A high indicator was found in the varieties Phoenix and Assol (90.2-95.7\% of the leaf surface).

Table 1. Drought resistance of promising varieties and forms of apple tree in the Crimea, 2017-2019.

\begin{tabular}{|c|c|c|c|c|c|c|}
\hline \multirow[t]{2}{*}{ № } & \multirow[t]{2}{*}{$\begin{array}{l}\text { Variety, } \\
\text { form }\end{array}$} & \multirow{2}{*}{$\begin{array}{l}\text { Total } \\
\text { water } \\
\text { content, \% }\end{array}$} & \multicolumn{3}{|c|}{$\begin{array}{l}\text { Loss of water by leaves during wilting (\%) (water- } \\
\text { holding capacity) }\end{array}$} & \multirow{2}{*}{$\begin{array}{l}\text { Turgor } \\
\text { restoration, } \\
\%\end{array}$} \\
\hline & & & $2 \mathrm{~h}$ & $4 \mathrm{~h}$ & $8 \mathrm{~h}$ & \\
\hline 1 & $\begin{array}{l}\text { Favorit* } \\
\text { control }\end{array}$ & $61.93 \pm 0.27$ & $28.41 \pm 0.85$ & $33.65 \pm 0.41$ & $58.45 \pm 0.52$ & $63.86 \pm 0.04$ \\
\hline 2 & Arbat* & $56.20 \pm 0.1$ & $54.17 \pm 0.63$ & $83.33 \pm 0.24$ & $95.83 \pm 1.1$ & $86.67 \pm 0.02$ \\
\hline 3 & Assol & $61.77 \pm 0.14$ & $39.52 \pm 0.77$ & $51.34 \pm 0.33$ & $58.33 \pm 0.84$ & $95.7 \pm 1.1$ \\
\hline 4 & Valyuta* & $61.87 \pm 0.23$ & $6.09 \pm 0.54$ & $12.04 \pm 0.84$ & $35.19 \pm 0.63$ & $78.24 \pm 0.03$ \\
\hline 5 & Phoenix & $57.63 \pm 0.17$ & $54.95 \pm 0.66$ & $72.16 \pm 0.25$ & $75.23 \pm 0.55$ & $90.21 \pm 0.98$ \\
\hline 6 & $2-5-25-80$ & $70.37 \pm 0.32$ & $4.59 \pm 0.48$ & $26.61 \pm 0.39$ & $42.43 \pm 0.74$ & $96.12 \pm 0.75$ \\
\hline 7 & $2-7-2-80$ & $60.73 \pm 0.12$ & $0.68 \pm 0.96$ & $26.05 \pm 0.51$ & $57.78 \pm 0.81$ & $73.35 \pm 0.14$ \\
\hline 8 & $2-11-7-80$ & $60.43 \pm 0.87$ & $15.5 \pm 0.55$ & $26.4 \pm 0.34$ & $41.56 \pm 1.73$ & $85.0 \pm 0.95$ \\
\hline 9 & $12-14-78$ & $57.30 \pm 2.07$ & $14.8 \pm 0.85$ & $20.35 \pm 1.1$ & $34.4 \pm 1.5$ & $81.3 \pm 0.35$ \\
\hline \multirow[t]{2}{*}{10} & $69-2-08 *$ & $32.41 \pm 0.10$ & $48.84 \pm 0.47$ & $67.44 \pm 0.14$ & $82.56 \pm 1.2$ & $66.86 \pm 0.04$ \\
\hline & $\mathrm{LSD}_{05}$ & 15.46 & & & & 17.64 \\
\hline
\end{tabular}

Note: * Columnar shape 
The control variety Favorit had a low turgescence (63.8\%). The sample 2-5-25-80 showed both high water-retention capacity and high turgescence $-96.12 \%$. Based on the data obtained, it can be concluded that this variety has high drought resistance, waterretaining ability and rapid turgor restoration.

The research results were used in the cluster analysis of varieties and forms, which were divided into groups. The first group - high water-holding capacity and high turgescence (12-14-78; 2-5-25-80; 2-11-7-80; Valyuta). The second group - average values for these indicators (2-7-2-80; Favorit). The third group - low water-holding capacity with high turgescence (Arbat and Phoenix). The fourth one - the average water-holding capacity with high turgescence (Assol). The fifth group - low water-holding capacity with average turgescence (69-2-08) (Fig. 1).

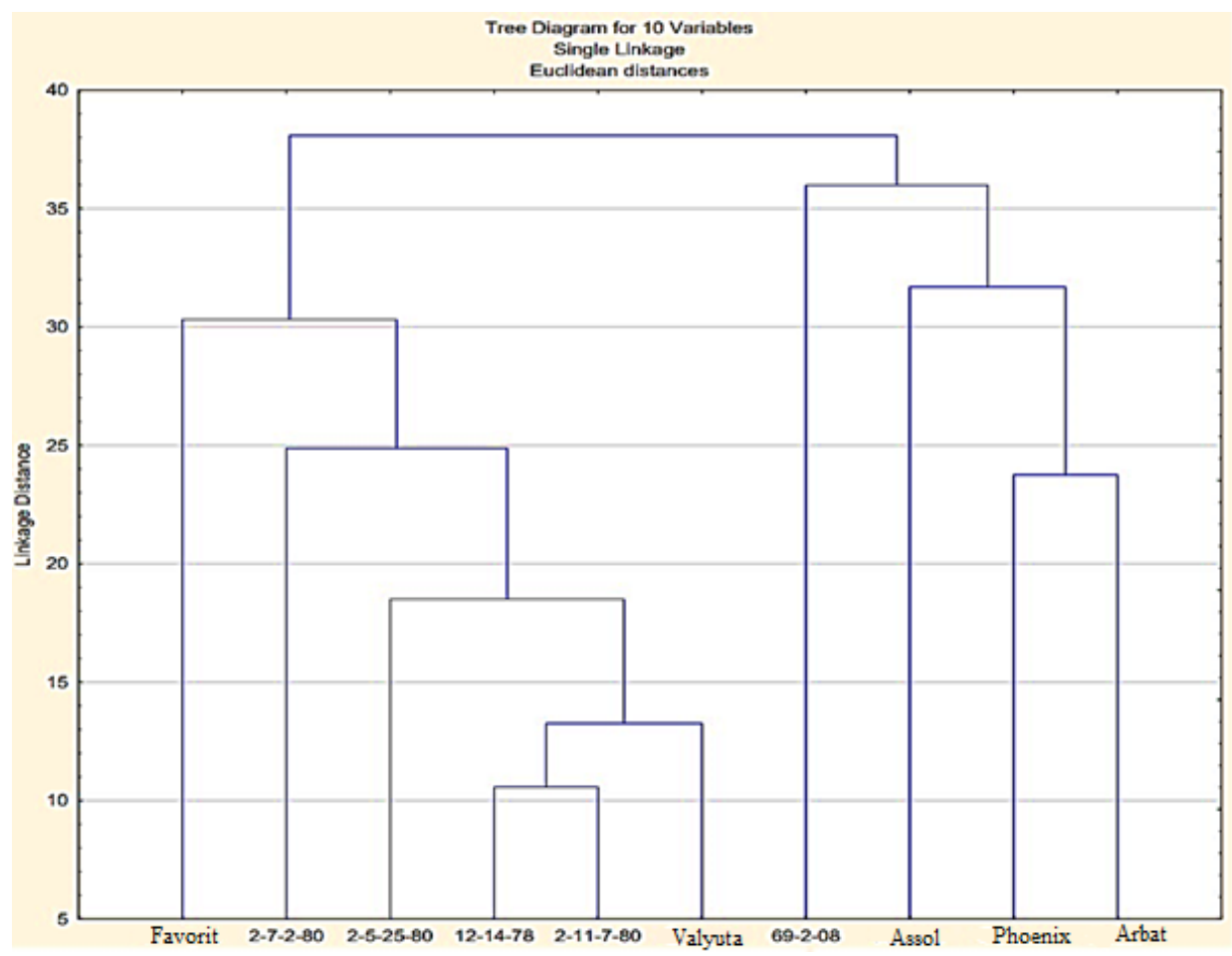

Fig. 1. Cluster analysis of drought resistance of apple tree varieties and forms.

These clusters can be grouped into two large groups: the first one - drought-resistant varieties and forms, which include samples: Valyuta, 2-5-25-80, 2-7-2-80, 2-11-78, 12-1478; the second one - varieties and forms relatively drought-resistant - Arbat, Phoenix, Assol. The first group of varieties manifests itself as drought-resistant, according to two components (water-holding capacity and turgescence). The second group of varieties has an average ability to retain moisture and a good ability to restore turgor after saturation. In the third group, as with a weak drought-resistant ability, the form 69-2-08 was included.

When studying the drought resistance of raspberry varieties according to water regime indicators, it was noted that the total water content in leaf tissues in the varieties ranged from 58.2 (Kovichan) to $67.47 \%$ (Patricia), Table 2. According to the water regime indicators, it was revealed that the water loss of the leaves during the 2-hour exposure varied within 3.4\% (breeding form 11/15) and 7.7 (Balsam), after 4 hours - 11.47 and 17.3 (in the same samples, respectively), and at 8-hour - 17.10 (Patricia) and 28.13 (Balsam). The dynamics of changes in the leaf water-retention capacity was high in the varieties: 
Patricia, Gusar, Krepysh, Glen Ampl and the breeding form 11/15. Leaves of the varieties Gusar, Krepysh, Glen Ampl and breeding form 11/15 restored the turgor best of all. The lowest level of water content recovery was showed in variety Balsam, Vikinite and Kovichan.

Cluster analysis was used to determine varietal differences. This method revealed the degree of similarity between the studied varieties, breeding forms and the control variety based on the Euclidean distance. All varieties are combined in the classification tree, which is reflected in the dendrogram (Fig. 2.).

Table 2. Drought resistance of promising raspberry varieties and forms in the Crimea, 2017-2019.

\begin{tabular}{|l|l|c|c|c|c|c|}
\hline \multirow{2}{*}{ No. } & \multirow{2}{*}{ Variety, form } & \multirow{2}{*}{$\begin{array}{c}\text { Total water } \\
\text { content, } \%\end{array}$} & \multicolumn{2}{|c|}{ Loss of water by leaves during wilting, (\%) } & \multirow{2}{*}{$\begin{array}{c}\text { Turgor } \\
\text { restoration, \% }\end{array}$} \\
\hline & & & & 4 hours & 8 hours & \\
\hline 1 & Balsam & & & & & \\
\hline 2 & Vikntrol) & $58.53 \pm 3.67$ & $7.7 \pm 3.80$ & $17.3 \pm 3.4$ & $28.13 \pm 0.27$ & 75 \\
\hline 3 & Glen Ampl & $62.93 \pm 2.67$ & $7.43 \pm 1.77$ & $13.97 \pm 1.73$ & $19.83 \pm 2.07$ & 75 \\
\hline 4 & Gusar & $63.9 \pm 0.8$ & $7.57 \pm 0.73$ & $13.2 \pm 0.7$ & $18.73 \pm 2.77$ & 95 \\
\hline 5 & Kovichan & $58.2 \pm 3.9$ & $5.83 \pm 2.57$ & $11.93 \pm 3.57$ & $17.17 \pm 4.13$ & 97 \\
\hline 6 & Krepysh & $61.83 \pm 1.37$ & $7.53 \pm 2.57$ & $13.27 \pm 3.23$ & $23.27 \pm 3.33$ & 80 \\
\hline 7 & Patricia & $67.47 \pm 2.93$ & $6.3 \pm 1.80$ & $12.03 \pm 3.5$ & $18.30 \pm 1.6$ & 97 \\
\hline 8 & Persea & $63.47 \pm 1.83$ & $5.9 \pm 4.40$ & $13.67 \pm 5.23$ & $24.03 \pm 3.7$ & 90 \\
\hline 9 & $11 / 15$ & $61.1 \pm 2.1$ & $3.4 \pm 1.00$ & $11.47 \pm 2.43$ & $18.87 \pm 1.83$ & 90 \\
\hline 10 & $28 / 15$ & $61.43 \pm 4.27$ & $7.73 \pm 2.77$ & $14.93 \pm 5.47$ & $24.20 \pm 2.4$ & 90 \\
\hline & LSD & 4.99 & 4.56 & 6.03 & 5.49 & 6.09 \\
\hline
\end{tabular}

According to trait similarity, all the studied samples can be grouped into clusters: the first one - high drought resistance: Glen Ampl, Krepysh, Gusar, 11/15; the second one medium drought resistance: Patricia, Persea, 28/15; the third one - below average: Kovichan, Vikinite and the control variety Balsam. It should be noted that in the breeding form 11/15, the drought resistance (9.5 points) was higher than the parent forms - Patricia and Perseus (9), in the breeding form 28/15 - at the level of the mother variety Perseus.

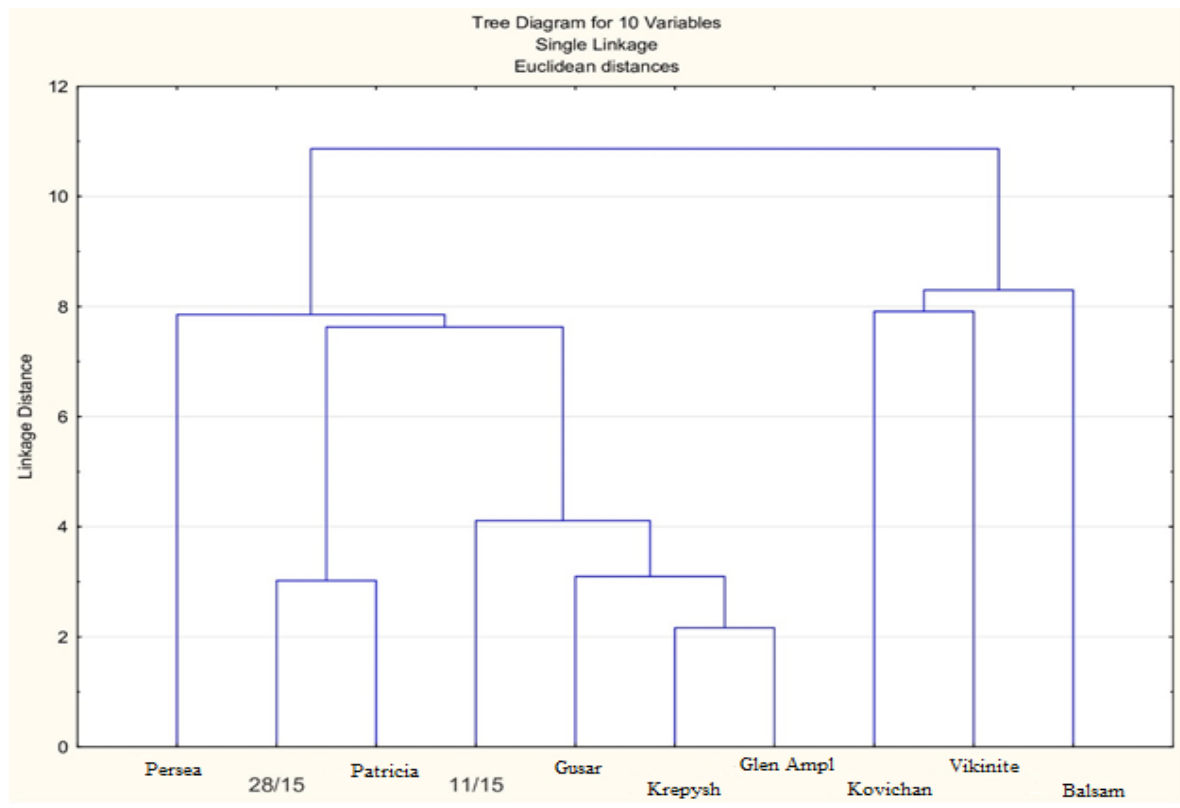

Fig. 2. Distribution of raspberry varieties and forms by drought resistance 


\section{Conclusions}

As a result of the research, a group of promising varieties and forms with high water retention and leaf turgescence was identified: apple tree - 12-14-78, 2-5-25-80, 2-11-7-80, Valyuta; raspberry - Glen Ampl, Gusar, Krepysh, 11/15. These genotypes are of great interest for introduction into production, as well as for inclusion in breeding programs for drought resistance trait.

Low drought resistance ( $33 \%$ of leaf surface is damaged), characteristic of the apple tree form 69-2-08. Some differences in the drought resistance of varieties can be explained by different mechanisms for ensuring plant resistance to water deficit.

\section{References}

1. G.N. Eremeev, Methods for assessing the stability of fruit crops, 101 (Kolos, 1976)

2. L.G. Kosulina, Physiology of plant resistance to adverse environmental factors (Publishing House of the Rostov University, 2011)

3. M.M. Okuntsov, Works of the Tomsk State University, 117, 165 (1952)

4. S. Zhao, Environmental and Experimental Botany, 180, 104246 (2020) https://doi.org/

5. S.N. Zakotenko, Industrial botanics, 2, 151 (2002).

6. N.G. Krasova, Horticulture and viticulture, 3, 18 (2016).

7. Z.E. Ozhereleva, N.G. Krasova, A.M. Galasheva, Achievements of science and technology of the agro-industrial complex, 33(2), 31 (2019)

8. I.V. Kazakov, Fruit and berry growing of Russia, 22(2), 64 (2009)

9. Z.E. Ozhereleva, N.I. Bogomolova, Modern Gardening, 2(10), 70 (2014)

10. V.V. Antyufeev, V.I. Vazhov, V.A. Ryabov, Climate Handbook of the Steppe Department of the Nikitsky Botanical Garden (2002).

11. V. I. Vazhov, Soil and climatic resources of the Crimea and rational placement of fruit crops: collection of scientific works, 71, 92 (1977).

12. N.E. Opanasenko, I.V. Kostenko, A.P. Yevtushenko Agroecological resources and zoning of steppe and foothill of the Crimea for fruit crops (Scientific world" LLC, 2015)

13. Yu.V. Plugatar, R.D. Babina, I.N. Suprun, T.S. Naumenko, Alekseev, Ya. I. Vavilovsky, Journal of Genetics and Breeding, 22(1), 60 (2018)

14. E.N. Sedov, Under the general editorship of E.N. Sedov, 608 (VNIISPK, 1999)

15. E.N. Sedov, Program and methodology of fruit, berry and nut crops breeding, 503 (1995)

16. G.N. Eremeev, A.I. Lischuk Guidelines for drought-resistant varieties and fruit plant rootstocks breeding, (1974)

17. B.A. Dospekhov, Methodology of field experience, 415 (Kolos, 1985)

18. V.P. Kazantsev, A.V. Bankrutenko, Field experience and basic methods of statistical analysis, 209 (Publishing House of the FSEI PHE OmSAU, 2010)

19. D. Geng, Horticulture research, 7(1), 1 (2020)

20. N. Parmar, Biotech, 7(4), 1 (2017)

21. W. S. Iljin, Review of Plant Physiology, 8(1), 257 (1957) 